\title{
KOKOSŲ IR SVIESTMEDŽIŲ ALIEJŲ PAGRINDU PAGAMINTŲ EMULSIJŲ POVEIKIS DEHIDRATUOTAI RANKŲ ODAI
}

\author{
Diana Barragan Ferrer, Žaneta Mickienė, Grèta Galkutė \\ Kauno kolegijos Medicinos fakultetas
}

Raktažodžiai: dehidratuota rankų oda, emulsija, kokosų aliejus, sviestmedžių aliejus.

\begin{abstract}
Santrauka
Rankų odos dehidratacija moterims tampa vis dažnesnè problema. Dèl dažno rankų plovimo, įvairių cheminių medžiagų naudojimo, aplinkos poveikio, odai tenka daugiau žalos ir joje pasireiškia ịvairūs pažeidimai. Svarbu žinoti, kaip to išvengti ir ką naudoti, kad būtų atkurta odos hidratacija ir sveika būklè. Pastaraisiais metais dažniau kalbama apie natūralios kosmetikos ingredientų naudingumą ir veiksmingumą. Skatinama naudoti augalinius aliejus, dèl didelio kiekio riebalų rūgščių, aktyviuju ingredientų bei jų natūralumo. Šiuo metu iš visų augalinių aliejų populiariausi yra du: kokosų ir sviestmedžių aliejus, kurie puikiai padengia odą apsaugine lipidine plèvele ir neleidžia drègmei išgaruoti iš odos sluoksnių. Natūralios kosmetikos gamintojai emulsijų gamybai naudoja ịvairius natūralius augalinius aliejus, todèl svarbu nustatyti, kaip skirtingi aliejai veikia dehidratuotą rankų odą. Šio tyrimo tikslas - nustatyti, koks kokosų ir sviestmedžių aliejų pagrindu pagamintų emulsijų poveikis dehidratuotai rankų odai. Tyrimo rezultatai parodè, kad dehidratuotą rankų odą efektyviau atkuria emulsija su kokosų aliejumi, nei su sviestmedžių aliejumi, tačiau emulsija su sviestmedžių aliejumi turẻjo ilgesni išliekamajj poveikį, nei su kokosų aliejumi.
\end{abstract}

\section{Ivadas}

Oda saugo organizmą nuo kenksmingų veiksnių: mikroorganizmų, ultravioletinių spindulių, alergenų ir kitų dirgiklių. Jos savitą funkciją lemia struktūra ir sudètis, ypač paviršinis sluoksnis, epidermis [1]. Dehidratuota, sausa rankų oda - tai būsena, paplitusi visoje populiacijoje [2]. Milijonai žmonių kasdien kenčia nuo rankų odos sausumo, niežulio, pleiskanojimo ir paraudimo [3]. Sutrikusią odos barjerinę funkciją, sumažejusị kraujagyslių jautrumą ir epidermio su- plonejjimą 10-50 proc. lemia padidèjęs odos pralaidumas, nepakankama lipidų sintezè ir pirmieji senejjimo požymiai [4]. Dažniausia odos išsausèjimo ir sudirginimo priežastis yra paviršiaus aktyviujų medžiagų ir tirpiklių, esančių agresyviose kasdienès higienos priemonėse, naudojimas, dažnas rankų plovimas, cheminių valymo tirpiklių sąlytis, išorès veiksniai arba profesine veikla [3]. Šiurkščios ir sausos odos būklès gydymas reikalingas ypatingo dėmesio, nes svarbu apsaugoti odą nuo esamų ir galimų neigiamų jos pokyčių. Kai odos šiurkštumas negydomas, odoje atsiranda ịvairių ịtrūkimų, didinančių uždegimo ar infekcijos riziką [5]. Galima teigti, kad tinkama rankų priežiūra ir apsauga gali sumažinti odos sausumą ir šiurkštumą [6]. Augaliniai aliejai jau seniai naudojami kosmetikoje ir medicininiais tikslais, nes buvo nustatyta daug teigiamų jų fiziologinių privalumų [1]. Aliejus ir vaškas kreme atlieka apsauginę funkciją nuo vandens netekimo epidermyje [7]. Jie pateikiami kaip saugūs komponentai, dažniausiai naudojami gaminant kosmetikos priemones [8]. Pavyzdžiui, augalinių aliejų naudojimas, darantis odai okliuzini poveikį, gali veikti kaip apsauginis barjeras, padedantis odai išlaikyti drègmę, sumažinti transepiderminio vandens netekimą. Be to, šių aliejų didesnis biologinis prieinamumas odoje ir jiems būdingas sisteminis poveikis. Fenoliniai junginiai ir tokoferoliai turi antioksidacini poveiki ir gali keisti fiziologinius procesus, tokius kaip odos barjero homeostazę, uždegimo mažinimą ir randų gijimą [1]. Natūralūs aliejai paprastai dar naudojami vietiniuose farmaciniuose preparatuose kaip emulsikliai, stabilizatoriai arba tirpumo stiprikliai [8]. Vieni iš populiariausių aliejų, naudojamų kosmetikos produktuose, yra kokosų ir sviesmedžių aliejai. Kokosų aliejuje yra daug laisvujų riebalų rūgščių, įskaitant laurino rūgštị (49 proc.), miristino rūgštị (18 proc.), palmitino rūgšti ( 8 proc.), kaprilo rūgšti ( 8 proc.), kaprino rūgšti (7 proc.), oleino rūgšti ( 6 proc.), linolo (2 proc.) ir stearino rūgštị (2 proc.). Šis aliejus ilgai laikomas neapkarsta [1].

Sviestmedžių aliejus susideda iš trigliceridų, kurių sudètyje yra oleino, stearino, linolo ir palmitino riebalų rūgščių. Dėl didelio aktyviujų medžiagų kiekio (t.y. triterpenų, tokoferolio, fenolių, sterolių), kurioms priskiriamos priešuždegi- 
minès ir antioksidacinès savybès, šis aliejus yra labai reikalingas kosmetikos pramoneje. Nustatyta, kad šis aliejus turi daug tokoferolio sudedamujų dalių, be to, jame yra keletas polifenolių, o jų koncentracija priklauso nuo ekstrahavimo metodo. Norint išlaikyti didesnị fenolinių junginių kieki sviestmedžio aliejuje, reikia keisti ekstrahavimo ir rafinavimo procesus [9].

Sviestmedžiu aliejuje daugiausia yra stearino ir oleino rūgšties, kurie kartu sudaro 85 - 90 proc. visų riebalų rūgščiu [10]. Honfo ir kt. (2014) teigia, kad sviestmedžio aliejuje yra $2-6$ proc. palmitino rūgšties [9]. Sviestmedžių aliejuje esantys biologiškai aktyvūs komponentai greitina žaizdelių gijimą, ramina sudirgusią odą, mažina niežèjimą, gydo odos išsausèjimą, slopina uždegimą, padeda probleminei odai.

Tyrimo tikslas - nustatyti, koks kokosų ir sviestmedžiu aliejų pagrindu pagamintų emulsijų poveikis dehidratuotai rankų odai.

\section{Tyrimo objektas ir metodika}

Tyrime dalyvavo penkios $19-25$ metų moterys. Keturios tiriamosios buvo dešiniarankès, o viena - kairiarankè (III tiriamoji).

Tyrime dalyvaujančių žmonių plaštakų oda buvo įvertinta „Soft Plus Skin Analyzer“ diagnostiniu aparatu renkantis programą „Hands“, kuria buvo analizuojami trys rankų odos būklès aspektai: hidratacija, riebumas ir elastingumas. Ivvertinama abiejų, dešiniosios ir kairiosios, rankų plaštakų būklè.

Odos diagnostika buvo atlikta:

- prieš pradedant tyrimą, esamajai rankų būklei nustatyti;

- viso eksperimento metu 4 kartus per mènesi, vieną

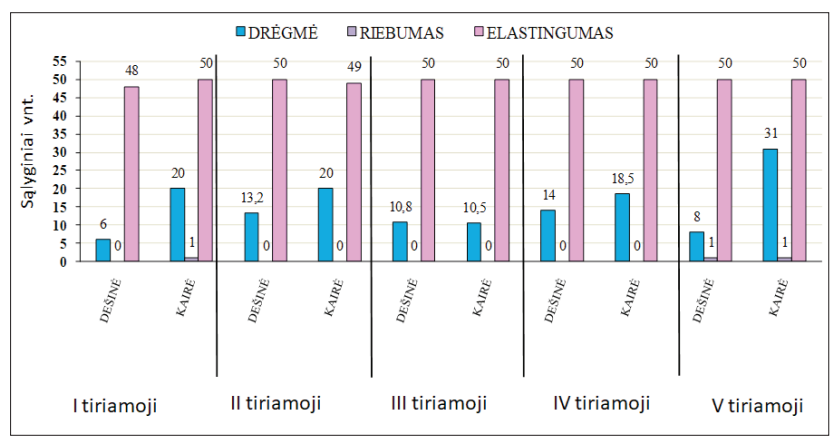

1 pav. Tiriamųų pradinè rankų plaštakų odos būklès diagnostika.

1 lentelè. Skaitinės reikšmės ir hidratacijos lygis, remiantis „Soft Plus Skin Analyzer" aparato instrukcijos aparšymu.

\begin{tabular}{|l|c|}
\hline Skaitinė reikšmė: & Odos hidratacija: \\
\hline $0-14$ & Labai dehidratuota \\
\hline $15-29$ & Dehidratuota \\
\hline $30-100$ & Normali \\
\hline
\end{tabular}

kartą per savaitę;

- tyrimo pabaigoje, praejjus $1-2$ savaitėms po kremų naudojimo.

Diagnostikos dieną tiriamosios kosmetinių preparatų rankų odai nenaudojo.

Atliekant diagnostiką ,,Skin Analyzer Soft Plus“ aparatu, vadovautasi taisyklemis. Aparatas nustato:

1) hidrataciją - drègmès lygị odoje. Prieš atliekant drègmès tyrimą, nurodomi amžiaus, lyties ir oro temperatūros rodikliai tiksliam rezultatui gauti. Matavimas vyksta 10-20 $\mu \mathrm{m}$ raginio sluoksnio gylyje. Diagnostinis aparatas rodo odos varžą, nes hidrolipidinèje plèvelèje ji yra tiesiogiai proporcinga vandens kiekiui. Tai leidžia spręsti apie vandens kiekį odoje. Drègmès lygis išreiškiamas žodine reikšme ir sąlyginiais vienetais, kurių tikslumas \pm 5 proc. $(\mathrm{p} \leq 0,05)$;

2) riebumą - odos išskiriamo sebumo kiekis, naudojant fotometrijos metodą. Specialus polimeras, apimantis maždaug $1 \mathrm{~cm}^{2}$ odos ploto, uždedamas ant centrinès plaštakos dalies ir laikomas apie 30 sekundžių, kad speciali juostelè

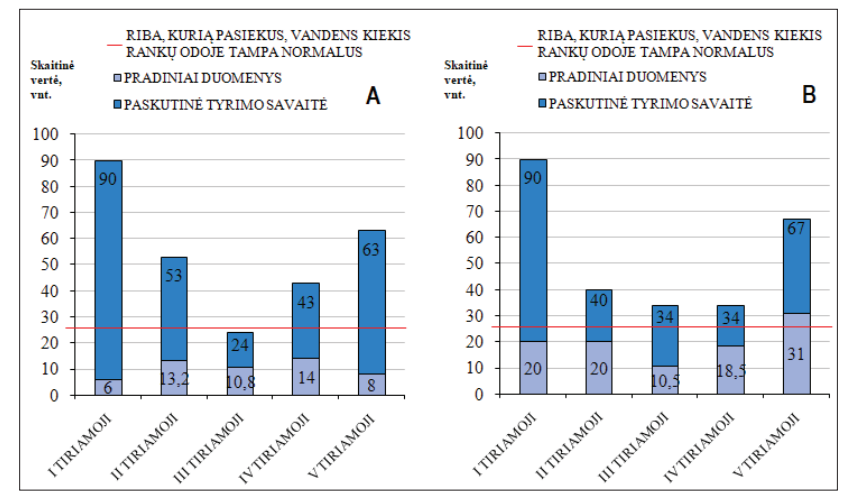

2 pav. Visų tiriamųų rankų odos hidratacijos kitimo rezultatai: A - dešiniosios rankos (naudota emulsija su kokosų aliejumi); B - kairiosios rankos (naudota emulsija su sviestmedžių aliejumi).

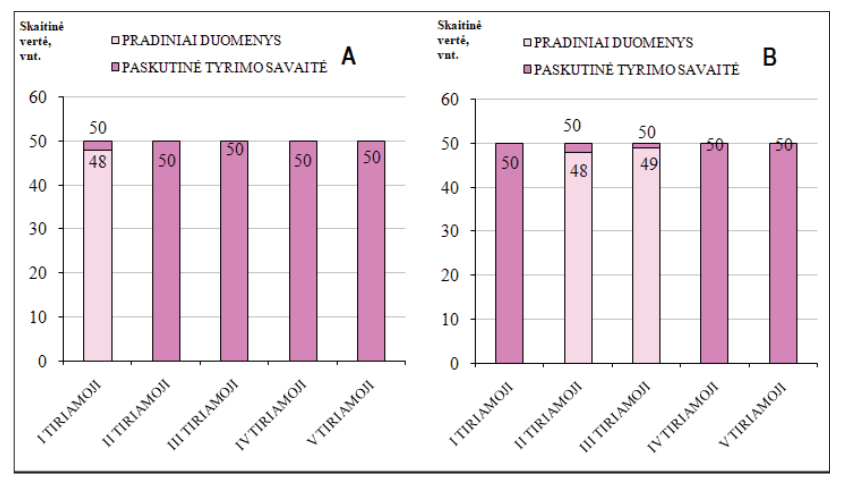

3 pav. Visų tiriamujų rankos odos elastingumo kitimo rezultatai: $\mathrm{A}$ - dešiniosios rankos (naudota emulsija su kokosų aliejumi); B - kairiosios rankos (naudota emulsija su sviestmedžių aliejumi). 
spètų absorbuoti riebalus. Perduodant panaudotą juostelès dali ị antgali, fotometrijos metodu nustatomas sebumo kiekis. Jo duomenys išreiškiami sąlyginiais vienetais ir žodine reikšme. Tikslumas \pm 5 proc. $(\mathrm{p} \leq 0,05)$;

3) elastingumą. Šiam rodikliui naudojamas elastometrijos būdas. Matavimas vyksta įtraukiant odą, ją deformuojant, kai veikia tam tikra mechaninè jèga. Taip ịvertinama funkcinè audinių būklè. Geras odos elastingumas nusakomas jos gebejjimu pasipriešinti neigiamam slègiui. Tikslumas \pm 10 proc. $(\mathrm{p} \leq 0,1)$.

Prieš pradedant naudoti emulsijas, atlikta pradinè tiriamujų dalyvių plaštakų odos būklès aparatinė diagnostika, kad būtų galima stebèti tolesnius eksperimento metu vyksiančius kitimus ir juos palyginti. Diagnostika buvo atliekama vieną kartą per savaitę, 4 kartus. Po to dvi savaites buvo stebimas išliekamasis emulsijų poveikis. Tiriamosioms buvo duotos dvi emulsijos: pirma - kokosų aliejaus pagrindu, antra sviestmedžių aliejaus pagrindu. Emulsija su kokosų aliejumi tepama ant dešiniosios plaštakos, o emulsija su sviestmedžiu aliejumi - ant kairiosios. Produktus buvo privaloma naudoti du kartus dienoje (ryte ir vakare). Kad emulsijos nesusimaišytų, jos buvo tepamos naudojant vienkartines pirštines. Tyrimo dalyvės viso eksperimento metu turejjo saugoti rankas, t. y. mūvèti pirštines esant sąlyčiui su vandeniu, cheminèmis, agresyviomis medžiagomis, vengti temperatūros pokyčių bei UV spindulių.

\section{Tyrimo rezultatai}

Emulsijų poveikis rankų odai. Prieš tyrimą buvo nustatyti pradiniai rankų odos būklès duomenys (1 pav.). Pradiniams rezultatams ịvertinti, remtasi diagnostikos aparato nurodytomis skaitinèmis vertemis (sąlyginiais skaitiniais vienetais).

„Soft Plus Skin Analyzer“ aparato instrukcijoje nuro-

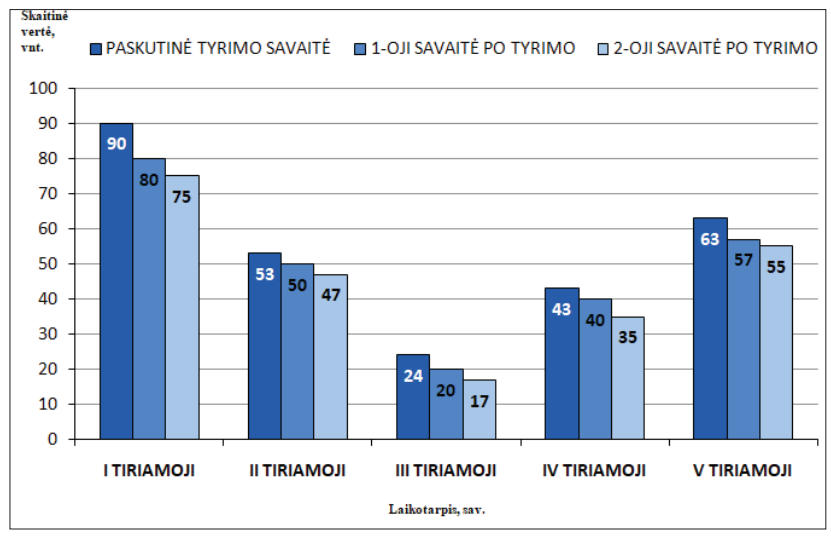

4 pav. Išliekamasis kokosų aliejaus poveikis dešiniosios rankos odos drègmès parametrui. dyti drègmès kiekio rankų odoje lygiai skaitiniais vienetais parodyti 1 lenteleje.

Gautieji pradinio tyrimo duomenys parodè, jog visų penkių tiriamujų dešinioji ranka yra labai dehidratuota. Hidratacijos skaitinè verte svyruoja nuo 6 iki 14 (1 pav.). Kairiojoje rankoje nustatyta mažesnè dehidratacijos vertė: vienos tiriamosios kairioji ranka buvo labai dehidratuota $(10,5$ sąlyginiu vienetų), trijų tiriamujų - dehidratuota (svyruoja nuo 18,5 iki 20 sąlyginių vienetų). Vienos tyrimo dalyvès (IV) kairiosios rankos drègmè nustatyta normali - 31. Rezultatai parodé, kad kairiosios rankos hidratacijos lygis yra didesnis, nei dešiniosios. Tai galima būtų paaiškinti tuo, kad dešinioji ranka dažniau naudojama ịvairiems kasdieniams darbams: rašymui, valgymui, valymui, telefonui ir t.t., todèl didesni ivvairių veiksnių poveikị patiria ir jos oda, išskyrus III-ios tiriamosios atveji, kuriuos kairioji ranka yra 0,3 sąlyginio vieneto labiau dehidratuota, nes dalyvė kairiarankè ir šią ranką naudoja daugiau. Penkių tiriamujų odos riebumo parametras parodè mažą skaitinę vertę, kuri svyravo nuo 0 iki 1, o tai reiškia, kad oda, pagal sebumo išskyrimą, yra sausa. Visų tiriamųjų odos diagnostikos aparatas riebumą įvertino 0 , išskyrus I-osios kairiają ranką (1) ir IV-osios abi rankas (1). Galima teigti, jog dominuoja sausa rankų oda. Elastingumas visų tiriamujų nustatytas kaip geras, svyruojantis nuo $48 \mathrm{iki}$ 50 sąlyginių vienetų. Atsižvelgiant ị tiriamujų amžiaus grupę, elastingumas dar nepakitęs.

Viso tyrimo metu kokosų ir sviestmedžių aliejų pagrindu pagamintos emulsijos turejo įtakos abiejų rankų odos hidratacijai. Gautieji duomenys parodè, kad visų tiriamųjų rankų odos drégmès lygis kilo, tačiau kilimo greitis buvo nevienodas, o priklausomas nuo emulsijoje esančio aliejaus. Ir kokosų, ir sviestmedžių aliejus per 4 naudojimo savaites atkūrè tiriamujų abiejų rankų odos hidratacijos lygị iš de-

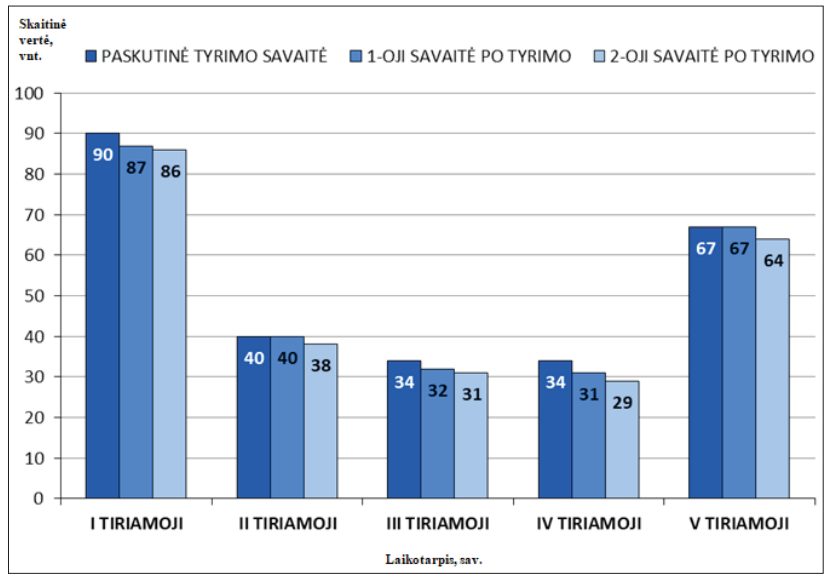

5 pav. Išliekamasis sviestmedžių aliejaus poveikis kairiosios rankos odos drègmès parametrui. 
hidratuotos į normalią odos būklę, išskyrus III tiriamosios dešiniają ranką. Rezultatams galèjo turèti ịtakos aplinkybès, kai tiriamoji 2 tyrimo savaitę buvo išvykusi atostogu i i šiltuosius kraštus, kuriuose karštas, sausas oras. UV spinduliai neigiamai veikè rankų odą, todèl hidratacijos rodikliai nukrito. Efektyviausias odos būklès pagerèjimas vandens lygio odoje atžvilgiu nustatytas I-ai tiriamajai. Dešiniojoje rankoje, kuri buvo tepta emulsija su kokosų aliejumi, drègmès kiekis, lyginant su pradine reikšme, padidejjo 15 kartų, o kairioji ranka, kuri buvo tepama emulsija su sviestmedžių aliejumi - 4,5 karto. Remiantis 4 savaičių tyrimo rezultatais nustatyta, kad kokosų aliejus greičiau ir efektyviau padidina drègmès kiekị net ir labai dehidratuotoje rankų odoje, nei sviestmedžių aliejus mažiau dehidratuotoje odoje (2 pav.).

Esant neigiamiems išorès veiksniams, sviestmedžių aliejus, nors ir nedaug, bet geriau apsaugojo odą nuo drègmès netekimo (remiantis IV-os ir V-os tiriamujjų tyrimų duomenimis), kai 3 savaitę IV tiriamoji ir 4 savaitę V tiriamoji ilgą laiką praleido šaltame ore, nemūvèdamos pirštinių. Drègmès lygis aukštesnis buvo toje rankoje, kuri buvo tepama emulsija su sviestmedžių aliejumi.

Apibendrinus tyrimo rezultatus galima teigti, kad kokosų aliejus efektyviau ir greičiau atkuria drègmès lygị rankų plaštakų odoje, tačiau, esant nepalankioms oro sąlygoms, tokioms kaip vejjas ir šaltis, emulsija su sviestmedžių aliejumi turi didesnị apsauginị poveikị negu emulsija su kokoso aliejumi. Drègmès efektyvesnį atsikūrimą lèmè kokosų aliejus todèl, kad savo struktūra būdamas artimas odos paviršiaus lipidų sluoksniui, geba paskatinti apsauginio barjero susiformavimą, kuris neleidžia išgaruoti drègmei.

Tiriant emulsijų poveikị odos riebumui nustatyta, kad augalinių, kokosų ir sviestmedžių aliejų pagrindu pagamintos emulsijos neturèjo įtakos abiejų rankų odos riebumui, nes duomenys nerodė nuoseklių pokyčių. Šie aliejai neskatina riebalinių liaukų sebumo išskyrimo, todèl riebumo tyrimo rezultatai buvo nereikšmingi.

Stebint odos elastingumo rodiklius buvo nustatyta, kad abi emulsijos turi poveikį rankų odos elastingumui. Kadangi tiriamosios buvo jauno amžiaus, elastingumo rodikliai aukšti, todèl tyrime buvo stebimas neženklus padidejimas tik tų tiriamujų, kurių elastingumas tyrimo pradžioje nesiekẻ maksimalios reikšmès, t.y 50 sąlyginių vienetų (3 pav.). I-osios tiriamosios dešiniosios rankos elastingumo rodiklis tyrimo pabaigoje pakilo 2 sąlyginius vienetus, II-osios tiriamosios kairiosios rankos pokytis buvo 2 sąlyginiai vienetai ir IIIiosios tiriamosios kairiosios rankos elastingumo rodiklis padidejo 1 sąlyginiu vienetu.

Išliekamasis emulsijų poveikis rankų odos hidratacijai. Praejjus keturioms tyrimo savaitėms naudojant emulsijas su kokosų ir sviestmedžių aliejais, visų penkių tiriamujų rankų odos hidratacija buvo atkurta iki normalios odos būklès. Aparatinè diagnostika dešiniajai (4 pav.) ir kairiajai (5 pav.) rankoms buvo atliekama du kartus: po tyrimo praejjus vienai ir dviem savaitems. Per šį laikotarpi tyrimo dalyvès nenaudojo nei šio eksperimento metu naudotų emulsijų, nei kitų pramoninių priemonių rankų odai. Buvo paprašyta, jog tiriamosios vengtų cheminių buitinių priemonių, jeigu neịmanoma - mūvètų apsaugines pirštines.

Atsižvelgus ị gautus duomenis, galima teigti, kad abiejų aliejų išliekamasis poveikis po dviejų tyrimo savaičių yra skirtingas. Nustatyta, kad sviestmedžių aliejus turi ilgesnị išliekamaji poveikị nei kokosų aliejus, nes sviestmedžių aliejuje daugiau yra stearino ir oleino rūgšties, šie komponentai efektyviau atkuria apsaugini barjerą ir pasižymi efektyvesniu okliuziniu poveikiu odai, nei kokoso aliejus [9].

\section{Išvados}

1. Nustatyta, kad emulsijos su kokosų ir su sviestmedžių aliejumi atkūrè visų tiriamujų abiejų rankų odos hidratacijos lygị iš dehidratuotos ị normalią būklę. Emulsijų poveikis skyrèsi. Kokosų aliejus turèjo greitesnį ir efektyvesnị drèkinamaji poveikị rankų odai, nes savo struktūra būdamas artimas odos paviršiaus lipidų sluoksniui, geba paskatinti apsauginio barjero susiformavimą, neleidžiantị išgaruoti drègmei.

2. Nustatyta, kad sviestmedžiu aliejus turi ilgesnị drègmès išliekamaji poveikị, nei kokosų aliejus, jo geresnè skvarba, vanduo bei muilas šios emulsijos gerai nenuplauna, todèl ji ilgiau išlieka odos sluoksniuose.

\section{Literatūra}

1. Lin K Z, Zhong L, Santiago J L. Anti-inflammatory and skin barrier repair effects of topical application of some plant oils. Int J Mol Sci 2017;19(1):1-21.

https://doi.org/10.3390/ijms19010070

2. Xhauflaire-Uhoda E, Piérard G E. Skin capacitance imaging of acne lesions Skin Res Technol 2007;13(1):9-12.

https://doi.org/10.1111/j.1600-0846.2006.00178.x

3. Draelos Z D, Matsubara A, Smiles K. The effect of $2 \%$ niacinamide on facial sebum production. Journal of Cosmetic and Laser Therapy 2005;8 (2):96-101. https://doi.org/10.1080/14764170600717704

4. Zouboulis C C, Makrantonaki E. Clinical aspects and molecular diagnostics of skin aging. Clin Dermatol 2011;29(1):3-14.

https://doi.org/10.1016/j.clindermatol.2010.07.001

5. Fowler J. Understanding the role of natural moisturizing factor in skin hydration. Pract Dermatol 2012; 9:36-40.

6. Kampf G, Ennen J. Regular use of a hand cream can attenuate skin dryness and roughness caused by frequent hand washing. BMC Dermatol 2006;6:1-5. 
https://doi.org/10.1186/1471-5945-6-1

7. Robinson M, Visscher M, Laruffa A, Wickett R. Natural moisturizing factors (NMF) in the stratum corneum (SC). II. Regeneration of NMF over time after soakin. J Cosmet Sci 2010;61(1):23-9.

8. Čižinauskas V, Elie N, Brunelle A, Briedis V. Skin penetration enhancement by natural oils for dihydroquercetin delivery. Molecules 2017;22(9):1536.

https://doi.org/10.3390/molecules22091536

9. Honfo G F, Akissoe N, Linnemann A R, Soumanou M, van Boekel M A J. S. Nutritional composition of shea products and chemical properties of shea butter: a review. Critical Reviews in Food Science and Nutrition 2014;54(5):673-686. https://doi.org/10.1080/10408398.2011.604142

10. Brewer M S. Natural antioxidants: sources, compounds, mechanisms of action, and potential applications. Compr. Rev. Food Sci. Food Saf. Wiley Online Library 2011;10:221-47. https://doi.org/10.1111/j.1541-4337.2011.00156.x

\section{THE EFFECT OF EMULSION BASED ON COCONUT AND SHEA BUTTER OILS FOR DEHYDRATION HAND SKIN}

D. Barragan Ferrer, Ž. Mickienė, G. Galkutė

Keywords: dehydrated hand skin, emulsion, coconut oil, shea butter oil.

\section{Summary}

The growing problem of hand skin dehydration in women has generated considerable attention in the cosmetic production. Numerous factors such as frequent handwashing, use of various chemicals and the exposure to the environment have been linked to this problem. In the face of this situation, natural cosmetic ingredients have proven to be useful to prevent and restore the skin hydration and help to promote the healthy skin. The use of vegetable oils has gained impetus due to the high content of fatty acids, active ingredients, and their natural origin. Currently, two of the most popular vegetable oils used are coconut and shea oil that show a protective coat to the skin with a lipid film to prevent moisture evaporation from the skin surface. Taking into account these characteristics, natural cosmetics manufacturers use a variety of natural vegetable oils to make emulsions. Therefore it is important to determine how different oils affect in the dehydration of skin of the hands. Thus, the purpose of this study is to determine the effect of coconut and shea oil-based emulsions on dehydrated hand skin. The results of this study showed that coconut oil is significantly more effective than shea oil to restore the dehydration of hand skin. However the shea oil emulsion had a long-lasting effect.

Correspondence to: diana.barragan.ferrer@go.kauko.lt

Gauta 2019-10-03

\section{KVIEČIAME PRENUMERUOTI “SVEIKATOS MOKSLŲ” ŽURNALĄ 2020 METAIS!}

Žurnalas "Sveikatos mokslai" (Index Copernicus, EBSCO host (Academic Search Complete), Gale (Academic OneFile), ProQuest (Ulrich's, Summon), Australia (ERA) 2012 Journal List (ERA ID 34962) skirtas visu specialybiu gydytojams, slaugytojams ir kitiems specialistams, spausdina mokslinius straipsnius lietuvių, anglų kalbomis. Reikalavimai straipsniams atitinka mokslo leidiniams keliamus reikalavimus. Žurnalas kioskuose neparduodamas. Žurnalą, kuris leidžiamas kartą per du mėnesius, galima užsiprenumeruoti visuose Lietuvos pašto skyriuose, taip pat internetu: www.prenumeruok.It

Prenumeratos kaina nesikeičia: visiems metams - 36 EUR, šešiems mėnesiams - 18 EUR, keturiems mėnesiams - 12 EUR, dviem mėnesiams - 6 EUR. Prenumeratos kodas: 5348.

Žurnalo autoriams straipsnių spausdinimas mokamas. 